\title{
Oxidative stability and lipid oxidation flavoring volatiles in antioxidants treated chicken meat patties during storage
}

\author{
Muhammad Sohaib ${ }^{1 *}$, Faqir Muhammad Anjum², Muhammad Sajid Arshad², Muhammad Imran ${ }^{3}$, Ali Imran ${ }^{3}$ \\ and Shahzad Hussain ${ }^{4}$
}

\begin{abstract}
Background: Chicken meat contains higher percentage of polyunsaturated fatty acids that are susceptible to oxidative deterioration ultimately leading towards lower consumer acceptability for chicken meat products. Accordingly, meat processing industries are looking for combinations of natural antioxidants to enhance the oxidative stability and consumer acceptability of meat based products. The present study aimed to investigate the influence of directly added quercetin dihydrate in combination with a-tocopherol on oxidative stability, color characteristics, total carbonyls and flavor volatile compounds in chicken meat patties.
\end{abstract}

Methods: Considering the preliminary studies, 3 levels of quercetin dihdrate @ 25, 50 and 100 mg/kg meat in combination with a-tocopherol at the rate 100 and $200 \mathrm{mg} / \mathrm{kg}$ meat were added to develop chicken meat patties and were stored at refrigeration temperature for 7 days. The oxidative stability of the antioxidant treated patties was determined by measuring malonaldehydes using TBARS and total carbonyls assay. The color (Lightness, redness and yellowness) of the patties was determined by using Konica Minolta Color Meter. Moreover, the volatile compounds were measured through gas chromatography at various storage intervals.

Results: The results elucidated that quercetin dehydrate inclusion at the rate of $50 \mathrm{mg} / \mathrm{kg}$ meat as well as particularly $100 \mathrm{mg} / \mathrm{kg}$ meat decreased the oxidation by reducing generation of malonaldehydes and total carbonyls in treated patties. Highest value for TBARS at initiation of storage was reported in $\left(T_{0}\right)$ as $1.93 \pm 0.02$ whereas lowest were reported in $T_{6}$ and $T_{5}$ as $0.37 \pm 0.01$ and $0.38 \pm 0.03$ that were increased to $3.47 \pm 0.14,0.90 \pm 0.05$ and $0.94 \pm 0.34$ at the completion of storage. Moreover, the lowest carbonyls also reported in T6 and the values at various storage intervals (1st, 3rd and 7th) were as $0.59 \pm 0.025,0.77 \pm 0.015$ and $1.02 \pm 0.031$, respectively. The antioxidants inclusion also inhibited volatile flavoring compounds particularly aldehydes like hexanal and pentanal in a dose dependent manner $(p \leq 0.05)$. Lowest hexanal values reported in $T_{6}$ as $2488 \pm 103$ followed by $T_{4}(3701 \pm 111)$ at the start of the trial whereas highest in $T_{0}$ (control) as $54,768 \pm 431$ that were increased to $9569 \pm 607,112,550 \pm 897$ and 359,826 \pm 1285 , correspondingly. The hexanal, as a critical indicator for the determination of volatiles in meat based products, was decreased with the addition of antioxidants and its highest values were reported in control group.

Conclusions: Quercetin dihydrate addition along with alpha tocopherol is a pragmatic choice to improve oxidative storability and volatile flavor compounds in cooked meat patties. The data obtained will help meat processor to better develop antioxidant enriched formulations to augment oxidative stability and quality of processed meat products.

Keywords: Antioxidants, Quercetin dihydrate, Volatiles, Hexanal, TBARS, Total carbonyls, Storability

\footnotetext{
*Correspondence: ftsohaib@yahoo.com; muhammad.sohaib@uvas.edu.pk 'Department of Food Science and Human Nutrition, University of Veterinary and Animal Sciences, Lahore 54000, Pakistan

Full list of author information is available at the end of the article
} 


\section{Background}

Lipid oxidation represents one of the most important causes of deterioration in meat and meat products and it affects unsaturated fatty acids particularly polyunsaturated fatty acids (PUFA) in membrane phospholipids as well as cholesterol, mainly low density lipoprotein (LDL) cholesterol. The final end-products of this process can damage the aroma, color, flavor as well as sensorial attributes of meat and allied products; hence reduce the nutritive value [1]. Besides nutritional deterioration, lipid oxidation generates cytotoxic and genotoxic compounds which are deleterious for humans health [2]. The oxidative damage to meat based products results in problems like tissues damaging, putrification, loss of nutrients, enhanced free radical generation and malonaldehydes production that reduce the antioxidant capacity of products [3]. Lipid stability of meat mainly depends on the balance of antioxidants, oxidation substrate, cholesterol content as well as heme pigment.

The quality defects caused by the oxidative process in meat and meat products can be controlled by using antioxidant based formulations and their incorporation disrupts the oxidation chain reaction that further progress with passage of time ultimately reduces quality of meat based products [4]. The quercetin is one of the flavonol and a potent antioxidant having ability to reduce lipid peroxidation in meat based products by limiting the oxidation chain reaction. The antioxidant activity of quercetin is attributed to its ability to scavenge free radicals, donate hydrogen atoms or electrons or chelate metal cations. Additionally, various in vitro and in vivo studies conducted on experimental animals revealed quercetin antioxidant and anti-inflammatory prospectives [5]. The oxidative stability of protein and lipids in meat and meat based products can be improved by the addition of $\alpha$ tocopherol due to its capacity to enhance the activity of cellular antioxidant enzymes. Moreover, addition of this antioxidants also improve color characteristics and overall quality attributes of chicken meat products [6]. It is also an essential micronutrient for maintaining the health and wellbeing of living organism due to antioxidant properties. Alpha tocopherol is the active form of vitamin $\mathrm{E}$ that is used in commercial formulations [7]. The addition of antioxidants rich formulations in various fresh and cooked meat products have potential to reduce oxidation problems by hindering the formation of free radicals. These additions beyond providing the protection against oxidative damage to meat products, also improve the safety and overall quality of processed meat products. Currently, meat processing industries are looking for natural antioxidant based formulations to enhance storability and volatile flavor compounds in cooked meat products. There is a dire need to develop formulations to be directly incorporated in meat products to retard lipid and protein oxidation as well as off flavor volatile compounds production. Considering these facts, present study was carried out to evaluate how much quercetin dihydrate alone as well as in combination with $\alpha$-tocopherol can be added to increase the oxidative stability as well as formation of off-flavor volatiles in chicken meat patties.

\section{Methods}

\section{Preparation of raw material and chemicals}

To carry out current study, chicken meat was purchased from a local superstore. Moreover, Quercetin dihydrate was procured from Alfa Aesar (Johnson Matthey Company, Massachusetts, USA). All other chemicals and reagents required were obtained from Sigma Aldrich (Japan) and Merck (Germany).

\section{Processing and application of antioxidants treatments in patties}

The meat was ground twice through a $10-\mathrm{mm}$ and a $3-$ mm plate (Kitchen Aid, Inc., St. Joseph, MI, USA) before the application of antioxidants. Based on the preliminary studies, following treatments were made; $\mathrm{T}_{0}=$ Control without antioxidants; $\mathrm{T}_{1}=25 \mathrm{mg}$ quercetin dihdrate + $100 \mathrm{mg} \alpha$-tocopherol $/ \mathrm{kg}$ meat; $\mathrm{T}_{2}=25 \mathrm{mg}$ quercetin dihdrate $+200 \mathrm{mg} \alpha$-tocopherol/kg meat; $\mathrm{T}_{3}=50 \mathrm{mg}$ quercetin dihdrate $+100 \mathrm{mg} \alpha$-tocopherol $/ \mathrm{kg}$ meat; $\mathrm{T}_{4}=$ $50 \mathrm{mg}$ quercetin dihdrate $+200 \mathrm{mg} \alpha$-tocopherol $/ \mathrm{kg}$ meat; $\mathrm{T}_{5}=100 \mathrm{mg}$ quercetin dihdrate $+100 \mathrm{mg} \alpha-$ tocopherol $/ \mathrm{kg}$ meat; $\mathrm{T}_{6}=100 \mathrm{mg}$ quercetin dihdrate + $200 \mathrm{mg} \alpha$-tocopherol $/ \mathrm{kg}$ meat. The quercetin dihydrate was dissolved in alkaline water for complete solublization. Moreover, $\alpha$-tocopherol is prepared by dissolving in corn oil before initiation of experiment. The aforementioned treatments were incorporated to the ground meat followed by mixing for 2 min using bowl mixer (Model KSM 90, St. Joseph, MI, USA). Afterwards, patties (100 \pm 3 g) were prepared, vacuum packaged in oxygen impermeable bags $\left(\mathrm{O}_{2}\right.$ permeability, $9.3 \mathrm{~mL} \mathrm{O}_{2} / \mathrm{m}^{2} / 24 \mathrm{~h}$ at $0{ }^{\circ} \mathrm{C}$, Koch, Kansas City, MO, USA) and cooked at $95{ }^{\circ} \mathrm{C}$ water bath (Fisher Scientific Inc., PA, USA) until the internal temperature reached to $75{ }^{\circ} \mathrm{C}$. The cooked patties were cooled and repacked in new oxygen permeable bags (polyethylene, $4 \times 6.2$ mil, Association Bags Co., Milwaukee, WI, USA) and stored at $4{ }^{\circ} \mathrm{C}$. The analyses of patties were carried out at $1 \mathrm{st}$, $3 \mathrm{rd}$ and 7 th day of storage.

\section{Analysis of patties}

\section{2-Thiobarbituric acid reactive substances (TBARS) analysis}

The oxidative stability of breast meat patties was estimated by using 2-thiobarbituric acid reactive substances (TBARS) according to the guidelines of [8]. In this context, $5 \mathrm{~g}$ of ground broiler meat samples were weighed 
in a $50 \mathrm{~mL}$ test tube and homogenized with $50 \mu \mathrm{L}$ of butylated hydroxytoluene (7.2\%) and $15 \mathrm{~mL}$ of deionized distilled water using a homogenizer for $15 \mathrm{~s}$. One $\mathrm{mL}$ of meat homogenate was transferred to a disposable test tube $(13 \times 100 \mathrm{~mm})$ and $2 \mathrm{~mL}$ of TBA/trichloroacetic acid (TCA; $15 \mathrm{mM}$ TBA/15\% TCA) solution was added. The mixture was vortex and incubated in a boiling water bath for $15 \mathrm{~min}$ to develop color. Afterwards, samples were cooled in ice water for $10 \mathrm{~min}$, vortex again and centrifuged for $15 \mathrm{~min}$ at $2000 \times g$ at $4{ }^{\circ} \mathrm{C}$. The absorbance of the resulting supernatant solution was determined at $531 \mathrm{~nm}$ against a blank containing $1 \mathrm{~mL}$ of deionized distilled water and $2 \mathrm{~mL}$ of TBA/TCA solution. The amounts of TBARS were expressed as milligrams of malondialdehyde (MDA)/kg meat.

\section{Color measurement}

The surface color of patties enriched with quercetin and $\alpha$-tocopherol was measured using Hunter-Lab Mini Scan XE colorimeter (Hunter Laboratory Inc., Reston, VA) with $\mathrm{D}_{65}$ illuminant and $10^{\circ}$ standard observer. Three readings for every sample were obtained and averaged for Commission Internationale d'Eclairage L* (lightness), $\mathrm{a}^{*}$ (redness) and $\mathrm{b}^{*}$ (yellowness) of patties.

\section{Volatile compounds}

The volatile compounds of cooked meat patties were measured through Solatek 72 Multimatrix-Vial Autosampler/Sample Concentrator 3100 (Tekmar-Dohrmann, Cincinnati, OH, USA) connected to GC/MS (Model 6890/5973; Hewlett-Packard Co., Wilmington, DE, USA) according to the method of [9]. Purposely, $2 \mathrm{~g}$ meat sample was placed in $40 \mathrm{~mL}$ sample vial, flushed with helium gas (40 psi) for $3 \mathrm{~s}$ and capped airtight with a Teflon"fluorocarbon resin/silicone septum (I-Chem Co., New Castle, DE, USA). The samples of different treatment were randomly organized on the refrigerated $\left(4{ }^{\circ} \mathrm{C}\right)$ holding tray to minimize the variation of the oxidative changes in samples. The meat samples were purged with helium $(40 \mathrm{~mL} / \mathrm{min})$ for $14 \mathrm{~min}$ at $20{ }^{\circ} \mathrm{C}$. The volatile compounds were trapped using Tenax/charcoal/silica column (Tekmar-Dohrmann) and desorbed for 2 min at $225{ }^{\circ} \mathrm{C}$, maintained in a cryofocusing module $\left(-70^{\circ} \mathrm{C}\right)$ and then thermally desorbed into a capillary column for $2 \mathrm{~min}$ at $225^{\circ} \mathrm{C}$. The HP-624 column $(7.5 \mathrm{~m}$, $0.25 \mathrm{~mm}$ i.d., $1.4 \mathrm{~mm})$, HP-1 column $(52.5 \mathrm{~m}, 0.25 \mathrm{~mm}$ i.d., $0.25 \mu \mathrm{m})$ and HP-Wax column $(7.5 \mathrm{~m}, 0.250 \mathrm{~mm}$ i.d., $0.25 \mu \mathrm{m}$ ) were connected through zero dead volume column connectors ( $\&$ W Scientific, Folsom, CA, USA). Initially, the oven temperature was $25^{\circ} \mathrm{C}$ for $5 \mathrm{~min}$ and increased to $85{ }^{\circ} \mathrm{C}$ at the rate of $40{ }^{\circ} \mathrm{C}$ per min leading to $165{ }^{\circ} \mathrm{C}$ at the rate of $20^{\circ} \mathrm{C}$ per min and finally $230{ }^{\circ} \mathrm{C}$ at $5{ }^{\circ} \mathrm{C}$ per min. held at this temperature for $2.5 \mathrm{~min}$. The constant column pressure 22.5 psi was maintained.
The ionization potential of mass spectrometer (MS) was $70 \mathrm{eV}$ with scan range 20.1 to $350 \mathrm{~m} / \mathrm{z}$. The identification of volatiles was accomplished using the Wiley Library (Hewlett-Packard Co.). The area of each peak was integrated using chemstation TM software (HewlettPackard Co.) and peak area (total ion counts $\times 10^{4}$ ) was calculated as an indicator of volatiles generated from meat samples.

\section{Protein oxidation (Total carbonyl) of meat patties}

The protein oxidation of patties at various storage intervals was measured by adopting the protocol of [10] with minor modifications. Purposely, $1 \mathrm{~g}$ sample was homogenized with Brinkman Polytron (Brinkman Instrument Inc., Westbury, NY, USA) in $10 \mathrm{~mL}$ of pyrophosphate buffer (2.0 mM Na4P2O7, $10 \mathrm{mM}$ Trizma-maleate), $100 \mathrm{mM} \mathrm{KCL}, 2.0 \mathrm{mM} \mathrm{MgCl} 2$, and $2.0 \mathrm{mM}$ ethylene glycol tetraacetic acid, pH 7.4). Two equal amounts of meat homogenate $(2 \mathrm{~mL})$ were taken from sample, precipitated with $2 \mathrm{~mL}$ of $20 \%$ trichloroacetic acid and centrifuged at $12,000 \times \mathrm{g}$ for $5 \mathrm{~min}$ at room temperature. After centrifugation, the pellet from 1 sample was treated with $2 \mathrm{~mL}$ of $10 \mathrm{mM}$ 2,4-dinitrophenylhydrazine dissolved in $2 \mathrm{M} \mathrm{HCL}$ and the pellet from other incubated with $2 \mathrm{M}$ HCL designated as blank. The samples were vortex-mixed for $10 \mathrm{~s}$ after every $3 \mathrm{~min}$ during 30 min incubation in the dark. Afterwards, the protein was precipitated with $2 \mathrm{~mL}$ of $20 \%$ trichloroacetic acid and centrifuged at $12,000 \times \mathrm{g}$ for $5 \mathrm{~min}$. The 2,4-dinitrophenylhydrazine was removed by washing 3 times with $4 \mathrm{~mL}$ of $10 \mathrm{mM} \mathrm{HCL}$ in 1:1 ( $\mathrm{vol} / \mathrm{vol}$ ) ethanol:ethyl acetate, followed by centrifuging at $12,000 \times \mathrm{g}$ for $5 \mathrm{~min}$. The pellets were finally solubilized in $2 \mathrm{~mL}$ of $6.0 \mathrm{mM}$ guanidine hydrochloride dissolved in $20 \mathrm{mM}$ potassium dihydrogen phosphate $(\mathrm{pH}=2.3)$. The samples were kept at $5{ }^{\circ} \mathrm{C}$ overnight and next day, they were centrifuged to remove insoluble materials. The absorbance of supernatant was recorded at $370 \mathrm{~nm}$ however absorbance for blank samples were subtracted from their corresponding values. Protein concentration was measured using Protein Assay Kit (Bio-Rad Lab, Hercules, CA, USA) following Microplate assay at $280 \mathrm{~nm}$ absorbance (BioTek-Gen5 Microplate data collection \& analysis software/BioTek Instruments, Inc., Model S4MLFPTA., Winooski, VT, USA). The carbonyl content was calculated as $\mathrm{nmol} / \mathrm{mg}$ protein using absorption coefficient of $22,000 / \mathrm{M} / \mathrm{cm}$.

\section{Statistical analysis}

Resultant data were analyzed by considered the complete randomized design using statistical package (Statistic 8.1). Moreover, Analysis of variance (ANOVA) was performed to measure the level of significance by following the guidelines of [11]. The Tukey's multiple range test 
was involved to estimate the level of significant among treatments and storage days.

\section{Results and discussion}

\section{Lipid oxidation of cooked meat patties}

The results (Fig. 1) regarding TBARS of quercetin dihdrate and $\alpha$-tocopherol treated patties delineated significant variations among treatments and storage. At storage initiation, TBARS in various groups $\mathrm{T}_{0}, \mathrm{~T}_{1}, \mathrm{~T}_{2}$, $\mathrm{T}_{3}, \mathrm{~T}_{4}, \mathrm{~T}_{5}$ and $\mathrm{T}_{6}$ were $1.93 \pm 0.02,0.80 \pm 0.01,0.66 \pm$ $0.06,0.63 \pm 0.05,0.58 \pm 0.02,0.38 \pm 0.03$ and $0.37 \pm 0.01$ that subsequently increased to $3.47 \pm 0.14\left(\mathrm{~T}_{0}\right), 2.97 \pm$ $0.09\left(\mathrm{~T}_{1}\right), 2.56 \pm 0.01\left(\mathrm{~T}_{2}\right), 2.43 \pm 0.04\left(\mathrm{~T}_{3}\right), 2.32 \pm 0.03$ $\left(\mathrm{T}_{4}\right), \quad 0.94 \pm 0.34\left(\mathrm{~T}_{5}\right), \quad 0.90 \pm 0.05\left(\mathrm{~T}_{6}\right) \mathrm{MDA} / \mathrm{kg}$ meat correspondingly at storage termination TBARS demonstrated a substantial increase ranged from 0.7641 , at initiation to 1.4754 and 2.2283 at 3rd and 7th day of storage, respectively.

During storage in meat based products, deterioration occurs through rancidity resulting from oxidation which takes place at the double bond sites in the triacyleglycerol molecules. It is evident from earlier studies that the oxidation process causes great economic loses to the food industry as well as consumers. Several studies showed that antioxidants especially quercetin dihydrates has ability to enhance the oxidative stability of cooked meat products [12]. The results for storability of nuggets are consistent with [13] noted the effect of antioxidants on TBARS of patties made from antioxidants enriched broiler meat. Likewise, [14] elucidated that antioxidant mixture containing quercetin and rutin at the rate of $0.05 \mathrm{~g} / 100 \mathrm{~g}$ meat have significant effect on inhibiting the MDA formation during shelf stability study of sausages. Similarly, [15] reported that chicken meat nuggets treated with antioxidants significantly decreased the MDA production however, with storage TBARS increased significantly. The oxidative modification of lipids has long been regarded as a deleterious process responsible for significant changes in the chemical properties of the molecules, loss of function and generation of cytotoxic and genotoxic compounds especially oxidized lipidsderived aldehydes and peroxides. Such lipid peroxidation products have much more stable state and therefore can easily diffuse from their site of generation to remote locations for damage to biological tissues $[16,17]$. The repeated consumption of such oxidized fats and fat containing products in the diet poses a chronic threat to human health by selective alterations in cell signaling, protein, DNA damage and dysfunction of organs such as liver, kidney, lung and the gut [18]. However, the oxidative stability of lipid fraction in complex food system is dependent on the composition, concentrations of reaction substrates, prooxidants and antioxidants. Therefore, decreasing the formation of lipid peroxidation products or scavenging them chemically could be beneficial in limiting the deleterious effects of reactive oxygen species in various pathological conditions. This could be potentially achieved by enhancing the endogenous oxidation control systems of foods through supplementation of antioxidants $[19,20]$.

\section{Color analysis}

The Fig. 2 depicted results for color attributes such as lightness $\left(\mathrm{L}^{*}\right.$-values), redness $\left(\mathrm{a}^{*}\right)$ and yellowness $\left(\mathrm{b}^{*}\right)$ that were affected by the treatments application. Among

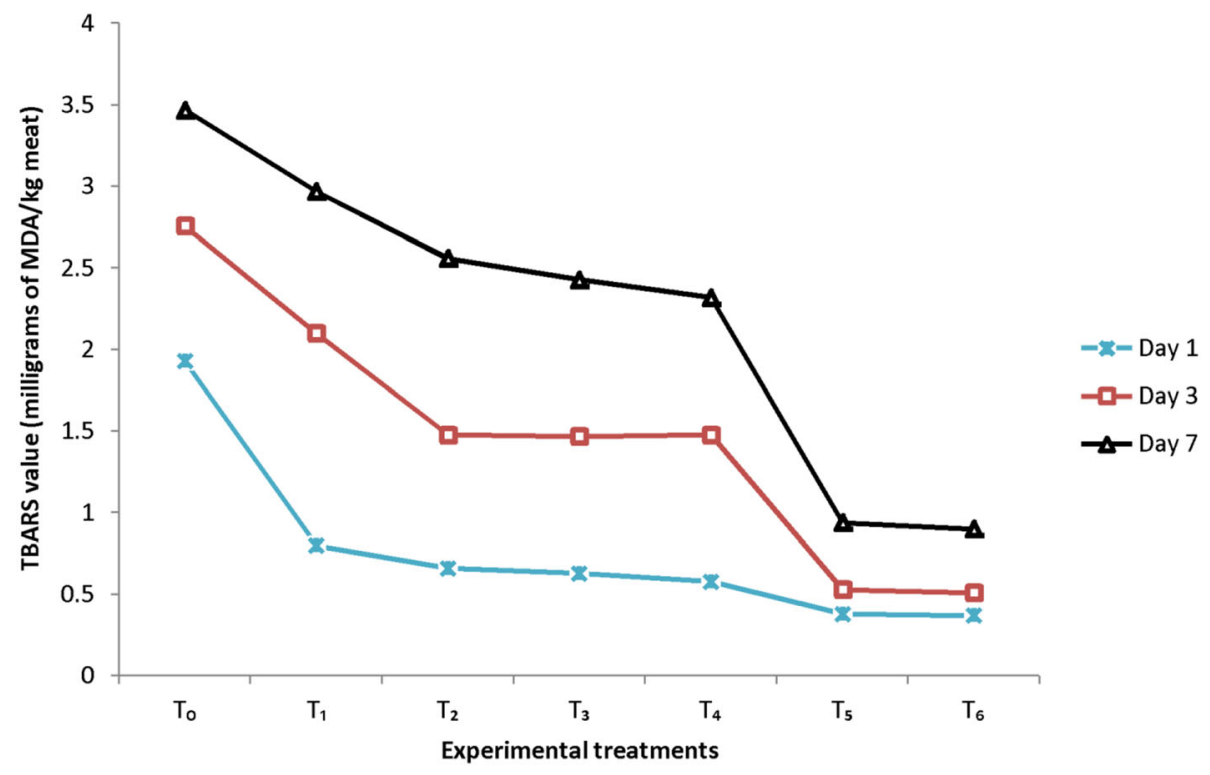

Fig. 1 TBARS of cooked breast meat patties stored at refrigeration conditions 

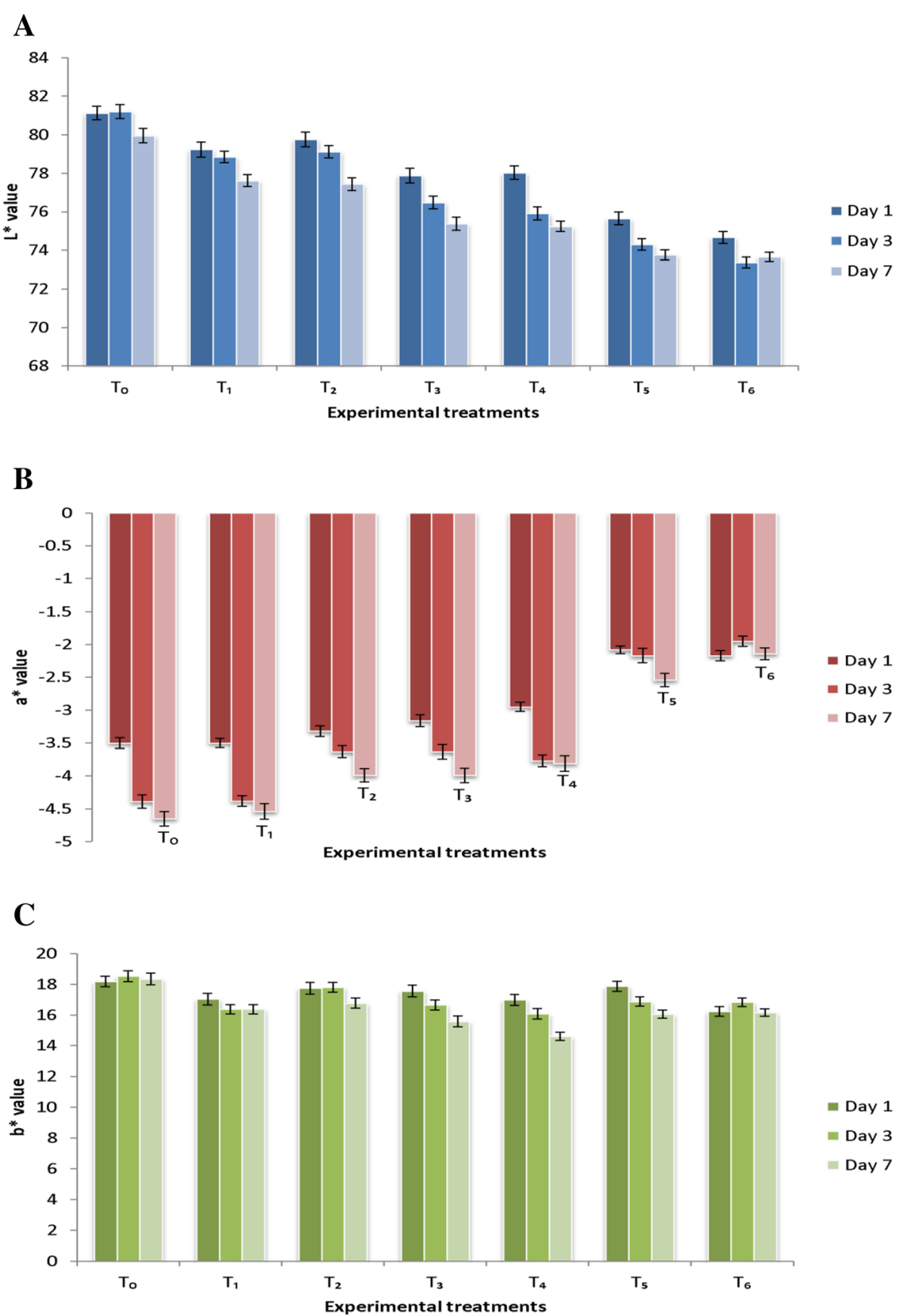

Fig. 2 Color values of cooked patties stored at $4{ }^{\circ} \mathrm{C}$ a Lightness $\left(L^{*}\right), \mathbf{b}$ Redness $\left(a^{*}\right)$ and $\mathbf{c}$ Yellowness $\left(b^{*}\right)$

treatments, maximum $\mathrm{L}^{*}$ value noticed in $\mathrm{T}_{0}$ (control) 80.773 whereas, the minimum 73.903 in $\mathrm{T}_{6}$. Likewise, $\mathrm{a}^{*}$ value also varied among treatments and with progress storage. Similarly, b* color values at initiation varied from $16.23 \pm 1.28$ to $18.18 \pm 0.23$. Current study findings are in agreement with [21], they reported a decrease in redness $\left(a^{*}\right)$ for patties with storage due to metmyoglobin accumulation. One of the researchers groups, [22] delineated that addition of vitamin E@200 and 300 ppm improve the visual color in meat product. Likewise, [23] reported that chicken meat balls containing pomegranate rind powder extract as source of antioxidants significantly $(p<$ 0.05 ) higher color nonetheless, this value decreased with storage. Similarly, [24] recorded lower discoloration $(p<0.05)$ in longissimus lumborum muscles for lambs meat fed on quercetin alone or in combination with flaxseed. 


\section{Protein oxidation}

The functional properties of proteins such as solubility, gelation and emulsification potential in different food products depend on their amino acid composition and structural arrangement. Oxidative deterioration of amino acids mainly lysine, proline, arginine and histidine can generate the carbonyl compounds that can affect the functionality of meat proteins especially in cooked meat products and antioxidants addition can decrease the rate of protein oxidation [25]. The results indicated that quercetin dihydrate and $\alpha$-tocopherol significantly $(p<$ $0.05)$ reduced the formation of the total carbonyl. The concentration of proteins carbonyls increased $(p \leq 0.05)$ treated groups. The results (Table 1) indicated that addition of quercetin dihydrate at the rate of $100 \mathrm{ppm}$ along with $\alpha$-tocopherol at the concentration of $100 \&$ 200 ppm showed the strongest potential in reducing total carbonyls and means reported lowest total carbonyls in $\mathrm{T}_{6}(0.7922)$ trailed by $\mathrm{T}_{5}$ and $\mathrm{T}_{4}(0.9256$ \& 1.3100) whereas, highest in $\mathrm{T}_{0}$ (1.7244). The formation of total carbonyls was consistent with TBARS in patties with storage progression and results are in harmony with [26] who reported that antioxidants addition decreased the formation of total carbonyls. Similarly, [27] indicated that mincing and high temperatures cooking can increase oxidation of protein in patties.

\section{Volatiles compounds in chicken meat patties}

The generation of off flavor is critical problem that can affect storage stability of cooked meat products [28]. The oxidation of polyunsaturated fatty acids results in the generation of volatile compounds which many have unpleasant odors and are responsible for the off-flavors in the food products [29]. Polyunsaturated fatty acids oxidation generates volatile compounds that impart undesirable aromas and lead towards compromising the nutritional quality of the meat and meat products with limited shelf life [30]. Oxidation is considered as one of the most common causes of flavor quality deterioration for meat based products during storage which accounts the great economic loses to the food industry and allied consumers. Adding $\alpha$-tocopherol and quercetin dehydrate significantly diminish the generation of off-odor volatiles in poultry meat (Tables 2, 3 and 4). Major volatiles identified in cooked patties were hydrocarbons, aldehydes, ketones, alcohols and sulfur compounds generated due to degradation of fatty acids and amino acids [31].

Hydrocarbons are among the major group of volatiles that can affect flavor of cooked products under storage. Major hydrocarbons reported in treated patties were pentane, heptane, 1-octene, octane, 2-octene and 1heptene. The generation of hydrocarbon was increased with progression of storage however, hydrocarbons increased linearly with quercetin dihydrate and $\alpha$ tocopherol in a dose dependent manner. On 1st day, Pentane, heptane, 1-octene, octane and 2-octene were ranged between $3013 \pm 188$ to $104,062 \pm 1824,349 \pm 29$ to $3808 \pm 129, \quad 352 \pm 31$ to $2239 \pm 109,6439 \pm 213$ to $32,775 \pm 976,191 \pm 11$ to $2533 \pm 109$, correspondingly. Heptane and octane were decreased with increasing level of antioxidants. However, storage progression, their amount was increased. 1-Heptane was not detected on 1 st day, however, 2-octene did not show clear trend but overall lower values were reported with increasing antioxidants concentration in meat samples. Likewise, on 7 th day highest pentane was recorded in $\mathrm{T}_{6}(78,607 \pm$ $319)$ followed by $T_{5}(71,928 \pm 317)$ and lowest in $T_{0}$ $(14,677 \pm 177)$, respectively.

The results showed aldehydes in patties were propanal, butanal, pentanal, hexanal, heptanal, octanal and nonanal and their concentration significantly $(p<0.05)$ decreased with increasing level of quercetin dihydrate and $\alpha$-tocopherol. At initiation of storage, maximum hexanal were reported in $\mathrm{T}_{0}$ (control) and lowest in $\mathrm{T}_{5}$ and $\mathrm{T}_{6}$ containing $100 \mathrm{ppm}$ quercetin dihydrate such as 54,768 $\pm 1431,3701 \pm 134,2488 \pm 103$ that were significantly increased to $359,826 \pm 1285,112,550 \pm 16,709,90,569 \pm$ 607 , respectively at storage termination. Similarly other volatiles like propanol, heptanal, octanal and nonanal were not detected in antioxidant added treatments and aldehydes showed a positive linear correlation with storage and treatments. Likewise, on 1st day lowest butanal and pentanal were found in $T_{6}$ followed by $T_{5}$, and $T_{4}$ and highest in $\mathrm{T}_{0}$ as $3462 \pm 91 \& 1222 \pm 45,3253 \pm 179$ \& $939 \pm 63,3399 \pm 152 \& 1626 \pm 69,3618 \pm 98$ \& 11,927 \pm 380 , correspondingly that were increased to $6153 \pm 134$ \& $13,840 \pm 186,7037 \pm 121 \& 21,064 \pm 247,9387 \pm 152$ $\& 59,438 \pm 314,10,892 \pm 131 \& 96,422 \pm 304$, respectively at the termination of the storage.

Among ketone group, only 2-propanone and 2butanone were recorded in patties samples. The results

Table 1 Protein oxidation of cooked breast meat patties stored at refrigeration temperature

\begin{tabular}{llllllll}
\hline Storage & $\mathrm{T}_{0}$ & $\mathrm{~T}_{1}$ & $\mathrm{~T}_{2}$ & $\mathrm{~T}_{3}$ & $\mathrm{~T}_{4}$ & $\mathrm{~T}_{5}$ & $\mathrm{~T}_{6}$ \\
\hline Day 1 & $0.71 \pm 0.015^{\mathrm{e}}$ & $0.70 \pm 0.021^{\mathrm{e}}$ & $0.69 \pm 0.020^{\mathrm{e}}$ & $0.66 \pm 0.015^{\mathrm{f,h}}$ & $0.65 \pm 0.015^{\mathrm{f,h}}$ & $0.63 \pm 0.015^{\mathrm{h}}$ & $0.59 \pm 0.025^{\mathrm{i}}$ \\
Day 3 & $1.55 \pm 0.026^{\mathrm{d}}$ & $1.42 \pm 0.021^{\mathrm{d}, \mathrm{e}}$ & $1.37 \pm 0.015^{\mathrm{e}}$ & $1.33 \pm 0.036^{\mathrm{e}, \mathrm{f}}$ & $1.25 \pm 0.015^{\mathrm{f}}$ & $0.88 \pm 0.031^{\mathrm{g}}$ & $0.77 \pm 0.015^{\mathrm{g}, \mathrm{e}}$ \\
Day 7 & $2.92 \pm 0.060^{\mathrm{a}}$ & $2.83 \pm 0.067^{\mathrm{a}, \mathrm{b}}$ & $2.77 \pm 0.038^{\mathrm{b}}$ & $2.16 \pm 0.050^{\mathrm{c}}$ & $2.03 \pm 0.026^{\mathrm{c}, \mathrm{d}}$ & $1.26 \pm 0.050^{\mathrm{f}}$ & $1.02 \pm 0.031^{\mathrm{f,g}}$ \\
\hline
\end{tabular}

${ }^{\mathrm{a}-\mathrm{i}}$ Means within a row or column with different superscript are statistically significant to each other $(p>0.05)$ 
Table 2 Volatile profile of cooked breast meat patties on 1st day of storage

\begin{tabular}{|c|c|c|c|c|c|c|c|}
\hline Compound & $\mathrm{T}_{0}$ & $\mathrm{~T}_{1}$ & $\mathrm{~T}_{2}$ & $T_{3}$ & $\mathrm{~T}_{4}$ & $\mathrm{~T}_{5}$ & $\mathrm{~T}_{6}$ \\
\hline Pentane & $3013 \pm 188^{c}$ & $33,820 \pm 1549^{b, c}$ & $49,361 \pm 1669^{a, b, c}$ & $85,936 \pm 1099^{a, b}$ & $30,246 \pm 1667^{b, c}$ & $71,611 \pm 1969^{a, b}$ & $104,062 \pm 1824^{a}$ \\
\hline Heptane & $3808 \pm 129^{a}$ & $2405 \pm 198^{a, b}$ & $573 \pm 49^{c}$ & $866 \pm 56^{c}$ & $771 \pm 65^{c}$ & $349 \pm 29^{c}$ & $986 \pm 83^{b, c}$ \\
\hline 1-octene & $352 \pm 31^{c}$ & $2239 \pm 109^{a}$ & $927 \pm 52 b^{c}$ & $441 \pm 37^{c}$ & $1029 \pm 81^{b, c}$ & $1012 \pm 92^{b, c}$ & $1810 \pm 152^{a, b}$ \\
\hline Octane & $32,775 \pm 976^{a}$ & $27,636 \pm 1058^{a}$ & $11,151 \pm 406^{b}$ & $6439 \pm 413^{b}$ & $8238 \pm 377^{b}$ & $6745 \pm 164^{b}$ & $7861 \pm 202^{b}$ \\
\hline 2-octene & $191 \pm 11^{\mathrm{b}}$ & $2044 \pm 103^{\mathrm{a}}$ & $1020 \pm 85^{a, b}$ & $1233 \pm 64^{a, b}$ & $1222 \pm 70^{a, b}$ & $1823 \pm 71^{a}$ & $2533 \pm 219^{a}$ \\
\hline 1-heptene & $0 \pm 0$ & $0 \pm 0$ & $0 \pm 0$ & $0 \pm 0$ & $0 \pm 0$ & $0 \pm 0$ & $0 \pm 0$ \\
\hline 2-propanone & $12,309 \pm 289^{a}$ & $12,328 \pm 266^{a}$ & $8047 \pm 224^{a}$ & $7990 \pm 207^{a}$ & $7081 \pm 237^{\mathrm{a}}$ & $6598 \pm 201^{a}$ & $6408 \pm 163^{a}$ \\
\hline 2-Butanone & $0 \pm 0^{a}$ & $0 \pm 0^{a}$ & $1562 \pm 121^{a}$ & $1485 \pm 88^{a}$ & $0 \pm 0^{a}$ & $0 \pm 0^{a}$ & $0 \pm 0^{a}$ \\
\hline Propanal & $0 \pm 0$ & $0 \pm 0$ & $0 \pm 0$ & $0 \pm 0$ & $0 \pm 0$ & $0 \pm 0$ & $0 \pm 0$ \\
\hline Butanal & $3618 \pm 98^{a}$ & $3257 \pm 199^{a}$ & $1475 \pm 121^{b}$ & $703 \pm 52^{b}$ & $3399 \pm 152^{\mathrm{a}}$ & $3253 \pm 179^{a}$ & $3462 \pm 91^{a}$ \\
\hline Pentanal & $11,927 \pm 380^{a}$ & $3391 \pm 104^{b}$ & $2431 \pm 96^{b}$ & $1874 \pm 45^{b}$ & $1626 \pm 69^{b}$ & $939 \pm 63^{b}$ & $1222 \pm 45^{b}$ \\
\hline Hexanal & $54,768 \pm 431^{a}$ & $11,568 \pm 283^{b}$ & $8902 \pm 383^{b}$ & $7367 \pm 318^{b}$ & $3701 \pm 111^{b}$ & $3759 \pm 34^{b}$ & $2488 \pm 103^{b}$ \\
\hline Heptanal & $1737 \pm 66^{a}$ & $0 \pm 0^{b}$ & $0 \pm 0^{b}$ & $0 \pm 0^{b}$ & $0 \pm 0^{\mathrm{b}}$ & $0 \pm 0^{b}$ & $0 \pm 0^{b}$ \\
\hline Octanal & $97 \pm 7^{a}$ & $0 \pm 0^{a}$ & $0 \pm 0^{a}$ & $0 \pm 0^{a}$ & $0 \pm 0^{a}$ & $0 \pm 0^{a}$ & $0 \pm 0^{a}$ \\
\hline Nonanal & $806 \pm 30^{a}$ & $0 \pm 0^{b}$ & $0 \pm 0^{b}$ & $0 \pm 0^{\mathrm{b}}$ & $0 \pm 0^{b}$ & $0 \pm 0^{b}$ & $0 \pm 0^{b}$ \\
\hline \multicolumn{8}{|l|}{ Alcohol } \\
\hline Cyclopentanol & $0 \pm 0$ & $0 \pm 0$ & $0 \pm 0$ & $0 \pm 0$ & $0 \pm 0$ & $0 \pm 0$ & $0 \pm 0$ \\
\hline Dimethyldisulfide & $4037 \pm 133^{a, b}$ & $5907 \pm 182^{\mathrm{a}}$ & $2596 \pm 216^{b}$ & $2081 \pm 239^{b}$ & $3410 \pm 217^{a, b}$ & $2215 \pm 105^{b}$ & $3918 \pm 175^{a, b}$ \\
\hline Benzoic acid & $364 \pm 26^{a}$ & $513 \pm 44^{a}$ & $0 \pm 0^{b}$ & $0 \pm 0^{b}$ & $0 \pm 0^{b}$ & $0 \pm 0^{b}$ & $0 \pm 0^{b}$ \\
\hline 1,3-octadiene & $0 \pm 0$ & $0 \pm 0$ & $0 \pm 0$ & $0 \pm 0$ & $0 \pm 0$ & $0 \pm 0$ & $0 \pm 0$ \\
\hline
\end{tabular}

${ }^{a-c}$ Means with in a row with different superscript are statistically significant to each other $(p>0.05)$

Table 3 Volatile profile of cooked patties on 3rd day of storage

\begin{tabular}{|c|c|c|c|c|c|c|c|}
\hline Compound & $\mathrm{T}_{0}$ & $\mathrm{~T}_{1}$ & $\mathrm{~T}_{2}$ & $T_{3}$ & $\mathrm{~T}_{4}$ & $\mathrm{~T}_{5}$ & $T_{6}$ \\
\hline Pentane & $12,877 \pm 79^{d}$ & $28,958 \pm 128^{c, d}$ & $83,941 \pm 145^{a}$ & $68,506 \pm 149^{a, b, c}$ & $22,902 \pm 132^{c, d}$ & $76,007 \pm 1710^{a, b}$ & $40,153 \pm 106^{a, b, c, d}$ \\
\hline Heptane & $1037 \pm 53^{c}$ & $3244 \pm 81^{a}$ & $2302 \pm 26^{a, b, c}$ & $2865 \pm 36^{a, b}$ & $1875 \pm 26^{a, b, c}$ & $998 \pm 34^{c}$ & $1584 \pm 31^{b, c}$ \\
\hline 1-octene & $0 \pm 0^{\mathrm{b}}$ & $1337 \pm 61^{\mathrm{a}}$ & $1276 \pm 56^{a}$ & $1237 \pm 84^{\mathrm{a}}$ & $1505 \pm 75^{\mathrm{a}}$ & $1198 \pm 46^{\mathrm{a}}$ & $1459 \pm 35^{\mathrm{a}}$ \\
\hline Octane & $10,753 \pm 149^{b, c, d}$ & $16,792 \pm 183^{a}$ & $13,030 \pm 107^{a, b, c, d}$ & $16,181 \pm 123^{a, b}$ & $14,604 \pm 104^{\mathrm{a}, \mathrm{b}, \mathrm{c}}$ & $7444 \pm 407^{d}$ & $10,071 \pm 98^{c, d}$ \\
\hline 2-octene & $729 \pm 36^{d}$ & $3690 \pm 116^{a, b}$ & $1586 \pm 66^{c, d}$ & $1970 \pm 83^{c, d}$ & $1835 \pm 78^{c, d}$ & $2412 \pm 86^{\mathrm{b}, \mathrm{c}}$ & $4666 \pm 116^{\mathrm{a}}$ \\
\hline 1-heptene & $109 \pm 9^{a}$ & $94 \pm 7^{a}$ & $0 \pm 0^{\mathrm{a}}$ & $0 \pm 0^{\mathrm{a}}$ & $0 \pm 0^{a}$ & $0 \pm 0^{\mathrm{a}}$ & $0 \pm 0^{\mathrm{a}}$ \\
\hline 2-propanone & $18,196 \pm 166^{a, b, c}$ & $16,417 \pm 124^{c}$ & $24,778 \pm 253^{a}$ & $20,207 \pm 136^{a, b, c}$ & $23,353 \pm 139^{a, b}$ & $19,291 \pm 132^{a, b, c}$ & $17,417 \pm 109^{b, c}$ \\
\hline 2-Butanone & $5650 \pm 62^{a, b}$ & $7274 \pm 88^{\mathrm{a}}$ & $6263 \pm 85^{a, b}$ & $7534 \pm 97^{a}$ & $9198 \pm 170^{\mathrm{a}}$ & $6257 \pm 107^{\mathrm{a}, \mathrm{b}}$ & $0 \pm 0^{\mathrm{b}}$ \\
\hline Propanal & $6830 \pm 189^{a}$ & $3726 \pm 104^{a, b, c}$ & $5078 \pm 111^{a, b}$ & $5971 \pm 115^{\mathrm{a}}$ & $4244 \pm 121^{\mathrm{a}, \mathrm{b}}$ & $1541 \pm 91^{c}$ & $1092 \pm 83^{b, c}$ \\
\hline Butanal & $8148 \pm 274^{\mathrm{a}}$ & $6656 \pm 60^{b}$ & $7201 \pm 145^{a, b}$ & $8099 \pm 201^{a}$ & $7220 \pm 174^{a, b}$ & $4223 \pm 140^{c}$ & $5229 \pm 110^{c}$ \\
\hline Pentanal & $61,228 \pm 1134^{a}$ & $39,879 \pm 936^{b}$ & $33,392 \pm 531^{b}$ & $38,633 \pm 596^{b}$ & $31,788 \pm 477^{b}$ & $4467 \pm 92^{c}$ & $7550 \pm 391^{c}$ \\
\hline Hexanal & $263,841 \pm 1239^{a}$ & $203,916 \pm 2406^{b}$ & $184,930 \pm 1765^{b}$ & $181,390 \pm 1446^{b}$ & $161,374 \pm 1088^{b}$ & $18,259 \pm 427^{c}$ & $9136 \pm 307^{c}$ \\
\hline Heptanal & $7313 \pm 53^{a}$ & $3892 \pm 79^{b}$ & $3909 \pm 60^{b}$ & $3379 \pm 89^{b}$ & $2896 \pm 75^{b}$ & $0 \pm 0^{c}$ & $0 \pm 0^{c}$ \\
\hline Octanal & $933 \pm 52^{\mathrm{a}}$ & $345 \pm 29^{b}$ & $461 \pm 37^{b}$ & $371 \pm 24^{b, c}$ & $285 \pm 17^{b, c}$ & $0 \pm 0^{c}$ & $0 \pm 0^{c}$ \\
\hline Nonanal & $1092 \pm 65^{a}$ & $738 \pm 37^{\mathrm{a}, \mathrm{b}}$ & $731 \pm 43^{a, b}$ & $664 \pm 46^{b}$ & $633 \pm 42^{b}$ & $0 \pm 0^{c}$ & $0 \pm 0^{c}$ \\
\hline Cyclopentanol & $0 \pm 0$ & $0 \pm 0$ & $0 \pm 0$ & $0 \pm 0$ & $0 \pm 0$ & $0 \pm 0$ & $0 \pm 0$ \\
\hline Dimethyldisulfide & $4968 \pm 126^{b, c}$ & $2633 \pm 143^{c, d}$ & $7229 \pm 194^{a, b}$ & $8168 \pm 190^{a}$ & $6123 \pm 154^{a, b}$ & $2524 \pm 148^{d}$ & $588 \pm 42^{d}$ \\
\hline Benzoic acid & $743 \pm 34^{\mathrm{a}}$ & $660 \pm 24^{a, b}$ & $352 \pm 21^{b, c}$ & $271 \pm 12^{c}$ & $0 \pm 0^{c}$ & $0 \pm 0^{c}$ & $0 \pm 0^{c}$ \\
\hline 1,3-octadiene & $0 \pm 0^{\mathrm{b}}$ & $462 \pm 23^{a}$ & $363 \pm 29^{a}$ & $418 \pm 12^{a}$ & $349 \pm 28^{a}$ & $0 \pm 0^{\mathrm{b}}$ & $0 \pm 0^{b}$ \\
\hline
\end{tabular}

${ }^{\mathrm{a}-\mathrm{d}}$ Means with in a row with different superscript are statistically significant to each other $(p>0.05)$ 
Table 4 Volatile profile of cooked patties on 7th day of storage

\begin{tabular}{|c|c|c|c|c|c|c|c|}
\hline Compound & $\mathrm{T}_{0}$ & $\mathrm{~T}_{1}$ & $T_{2}$ & $T_{3}$ & $\mathrm{~T}_{4}$ & $\mathrm{~T}_{5}$ & $T_{6}$ \\
\hline Pentane & $14,677 \pm 177^{b}$ & $27,436 \pm 128^{a, b}$ & $48,133 \pm 182^{a, b}$ & $31,390 \pm 197^{a, b}$ & $23,013 \pm 101^{a, b}$ & $71,928 \pm 317^{a, b}$ & $78,607 \pm 319^{a}$ \\
\hline Heptane & $5114 \pm 168^{a}$ & $3916 \pm 114^{a, b}$ & $3531 \pm 124^{b, c}$ & $1985 \pm 140^{d}$ & $2604 \pm 109^{c, d}$ & $2002 \pm 72^{d}$ & $1557 \pm 63^{d}$ \\
\hline 1-octene & $0 \pm 0^{d}$ & $1200 \pm 31^{b, c}$ & $822 \pm 47^{b, c, d}$ & $355 \pm 28^{c, d}$ & $593 \pm 26^{c, d}$ & $1789 \pm 38^{a, b}$ & $2337 \pm 41^{\mathrm{a}}$ \\
\hline Octane & $13,920 \pm 181^{a, b}$ & $16,972 \pm 174^{a}$ & $12,739 \pm 176^{a, b, c}$ & $9029 \pm 180^{c, d}$ & $11,830 \pm 153^{b, c, d}$ & $11,574 \pm 168^{b, c, d}$ & $8083 \pm 107^{d}$ \\
\hline 2-octene & $1075 \pm 44^{c}$ & $3327 \pm 48^{a, b}$ & $2111 \pm 26^{b, c}$ & $1383 \pm 24^{c}$ & $1841 \pm 37^{b, c}$ & $3368 \pm 57^{a, b}$ & $4505 \pm 35^{\mathrm{a}}$ \\
\hline 1-heptene & $291 \pm 19^{a, b}$ & $547 \pm 22^{a}$ & $210 \pm 15^{a, b}$ & $129 \pm 11^{b}$ & $120 \pm 9^{b}$ & $0 \pm 0^{b}$ & $0 \pm 0^{b}$ \\
\hline 2-propanone & $15,113 \pm 104^{c}$ & $17,980 \pm 114^{c}$ & $21,044 \pm 195^{\mathrm{b}, \mathrm{c}}$ & $20,689 \pm 107^{b, c}$ & $27,303 \pm 163^{a, b}$ & $32,990 \pm 221^{a}$ & $33,102 \pm 228^{a}$ \\
\hline 2-Butanone & $5661 \pm 96^{b}$ & $7826 \pm 82^{b}$ & $9716 \pm 87^{a, b}$ & $9680 \pm 85^{a, b}$ & $11,751 \pm 101^{\mathrm{a}, \mathrm{b}}$ & $14,666 \pm 107^{\mathrm{a}}$ & $10,120 \pm 84^{\mathrm{a}, \mathrm{b}}$ \\
\hline Propanal & $8421 \pm 142^{\mathrm{a}}$ & $6060 \pm 169^{a}$ & $7241 \pm 189^{a}$ & $7241 \pm 133^{\mathrm{a}}$ & $9038 \pm 154^{\mathrm{a}}$ & $6115 \pm 157^{\mathrm{a}}$ & $2948 \pm 91^{a}$ \\
\hline Butanal & $10,892 \pm 131^{a}$ & $8833 \pm 126^{a, b, c}$ & $9592 \pm 145^{a, b}$ & $8321 \pm 229^{b, c, d}$ & $9387 \pm 152^{a, b}$ & $7037 \pm 121^{\mathrm{cd} d}$ & $6153 \pm 134^{d}$ \\
\hline Pentanal & $96,422 \pm 304^{a}$ & $65,251 \pm 384^{b}$ & $69,319 \pm 335^{b}$ & $56,315 \pm 3432^{b}$ & $59,438 \pm 314^{b}$ & $21,064 \pm 247^{c}$ & $13,840 \pm 186^{c}$ \\
\hline Hexanal & $359,826 \pm 1285^{a}$ & $279,277 \pm 1048^{\mathrm{b}, \mathrm{c}}$ & $286,879 \pm 1048^{b}$ & $239,163 \pm 1104^{c}$ & $244,203 \pm 999^{c}$ & $112,550 \pm 897^{d}$ & $9569 \pm 607^{e}$ \\
\hline Heptanal & $13,046 \pm 118^{\mathrm{a}}$ & $7073 \pm 81^{b}$ & $8339 \pm 73^{b}$ & $5764 \pm 65^{b}$ & $6409 \pm 67^{b}$ & $1744 \pm 46^{c}$ & $330 \pm 23^{c}$ \\
\hline Octanal & $2455 \pm 46^{a}$ & $856 \pm 34 b^{c}$ & $1726 \pm 32^{a, b}$ & $633 \pm 26^{c}$ & $949 \pm 37^{b, c}$ & $0 \pm 0^{c}$ & $0 \pm 0^{c}$ \\
\hline Nonanal & $1974 \pm 21^{a}$ & $1530 \pm 27^{a, b}$ & $1406 \pm 23^{b, c}$ & $983 \pm 16^{c}$ & $1082 \pm 39^{b, c}$ & $313 \pm 18^{d}$ & $0 \pm 0^{d}$ \\
\hline Cyclopentanol & $1682 \pm 33^{a}$ & $788 \pm 23^{b}$ & $658 \pm 26^{b, c}$ & $247 \pm 17^{c, d}$ & $161 \pm 9^{d}$ & $0 \pm 0^{d}$ & $0 \pm 0^{d}$ \\
\hline Dimethyldisulfide & $4159 \pm 146^{\mathrm{a}}$ & $3843 \pm 132^{\mathrm{a}}$ & $5492 \pm 154^{\mathrm{a}}$ & $3427 \pm 147^{a}$ & $4454 \pm 113^{\mathrm{a}}$ & $3263 \pm 101^{a}$ & $2916 \pm 75^{a}$ \\
\hline Benzoic acid & $889 \pm 24^{a}$ & $916 \pm 28^{a}$ & $480 \pm 14^{a, b}$ & $263 \pm 15^{b, c}$ & $678 \pm 31^{a, b}$ & $0 \pm 0^{c}$ & $0 \pm 0^{c}$ \\
\hline 1,3-octadiene & $193 \pm 11^{b}$ & $421 \pm 21^{a, b}$ & $847 \pm 26^{a}$ & $88 \pm 7^{b}$ & $813 \pm 19^{a}$ & $352 \pm 22^{b}$ & $412 \pm 14^{a, b}$ \\
\hline
\end{tabular}

${ }^{a-e}$ Means with in a row with different superscript are statistically significant to each other $(p>0.05)$

further indicated that on 1st day, lowest 2-propanone was found in $\mathrm{T}_{6}(6408 \pm 163)$ followed by $\mathrm{T}_{5}$ and $\mathrm{T}_{4}$ that were $6598 \pm 201,7081 \pm 237$ and highest in $\mathrm{T}_{0}$ as $12,309 \pm 289$ that were increased to $33,102 \pm 228,32,990 \pm 221,27,303 \pm$ 163 and $15,113 \pm 104$ at termination of storage. 2-Butanone results showed that on day 1 st, they were detected in $T_{2}$ and $\mathrm{T}_{3}$ only while at the completion of storage, lowest were found in $T_{0}$ and highest in $T_{5}$ as $5661 \pm 96,14,666 \pm 107$, correspondingly. Similarly, others volatiles reported in patties were dimethyldisulfide, benzoic acid and 1,3-octadiene. Dimethyl sulfide content decreased with storage however, benzoic acid and 1,3-octadiene were not consistent among treatments and with storage. Besides, different does of quercetin dehydrate and alpha tocopherol in meat patties, storage is also a prominent factor that influenced the production of off flavor volatile compounds and its production especially aldehyde including hexanal, pentnal, butanal, heptanal etc. increased with storage production. The incorporation of antioxidants significantly reduces the rate of volatiles generation and current study results are supported by [32] who reported positive relation between aldehyde compounds and TBARS in chicken meat. Similarly, [33] also narrated that aldehyde presence in cooked meat is mainly attributed to lipid degradation that is enhanced with cooking and storage. Hexanal, an important aldehyde that can generate grassy aroma note [34] is among the most abundant aldehyde fund in meat based products. This hexanal is mostly generated from fatty acids degradation as poultry meat is rich source of polyunsaturated fatty acids [35]. Similarly, [36] noticed sulfur volatiles escaped after 5 day storage due to their high volatility.

\section{Conclusion}

Current study findings revealed that addition of quercetin dihdrate alone as well as in combination with $\alpha$ tocopherol improved oxidative stability, total carbonyls as well as volatile off flavor compounds in treated chicken patties. Quercetin dihdrate incorporation at a level of $100 \mathrm{mg} / \mathrm{kg}$ meat with $\alpha$-tocopherol at the rate of 100 and $200 \mathrm{mg} / \mathrm{kg}$ meat delayed lipid and protein degradation by inhibiting oxidation of cooked meat products. Additionally, quercetin dihydrate addition also decreased the aldehydes volatiles particular hexanal and pentanal that are considered as a major index to judge the storability of cooked meat products. Furthermore, preliminary studies showed that using quercetin along gives better oxidative and volatiles generation results than that of $\alpha$-tocopherol however, quercetin alone imparts yellowness thereby using it in combination with $\alpha$ tocopherol is a better choice to enhance the oxidative stability and quality of processed poultry meat products. The current exploration concluded quercetin dihdrate along with $\alpha$-tocopherol is a pragmatic choice to enhance the oxidative stability by inhibiting the production of malonaldehydes and total carbonyls as well as volatile flavor compounds in cooked chicken meat products. 


\section{Acknowledgement}

The authors are highly obliged to the Library Department, Government College University Faisalabad (GCUF) and IT Department, Higher Education Commission (HEC, Islamabad) for access to journals, books and valuable database.

\section{Funding}

The authors are grateful to Higher Education Commission (HEC), Government of Pakistan for their financial support to carry out the present research.

\section{Availability of data and materials}

The dataset supporting the conclusions of this article is included within the article.

\section{Authors' contributions}

The contribution of the each author for this paper was as follows, MS and FMA designed the experimental study for exploring the effect of quercetin dihydrate in combination with alpha tocopherol on oxidative stability, color characteristics and volatiles using meat model system. MS carried out the trials and collected data as well as drafted the manuscript. MSA, MI, Al and $\mathrm{SH}$ provide technical assistance regarding research and data interpretation. It is evident that all authors read and approved the final manuscript.

\section{Competing interests}

The authors declare that they have no competing interests.

\section{Consent for publication}

Not Applicable.

\section{Ethics approval and consent to participate}

Not Applicable.

\section{Author details}

${ }^{1}$ Department of Food Science and Human Nutrition, University of Veterinary and Animal Sciences, Lahore 54000, Pakistan. ${ }^{2}$ Institute of Home and Food Sciences, Faculty of Science and Technology, Government College University, Faisalabad 38040, Pakistan. ${ }^{3}$ Department of Food Science, Nutrition and Home Economics, Government College University, Faisalabad, Pakistan. ${ }^{4}$ Department of Food Science and Nutrition, College of Food and Agricultural Sciences, King Saud University, Riyadh, Saudi Arabia.

Received: 9 September 2016 Accepted: 26 January 2017 Published online: 01 February 2017

\section{References}

1. Luna A, Labaque M, Zygadlo M, Marin R. Effects of thymol and carvacrol feed supplementation on lipid oxidation in broiler meat. Poult Sci. 2010;89. 366-70.

2. Botsoglou E, Govaris A, Ambrosiadis I, Fletourisc D, Papageorgioud G. Effect of olive leaf (Olea europea L.) extracts on protein and lipid oxidation in cooked pork meat patties enriched with n-3 fatty acids. J Sci Food Agric. 2014;94:227-34

3. Ahn DU, Nam KC, Lee EJ. Lipid oxidation and flavor. Appl Muscle Biol Meat Sci. 2009;12:227-46.

4. Ennajar M, Bouajila J, Labrini A, Mathieu F, Abderraba M, Raies A, Romdhane M. Chemical composition and antimicrobial and antioxidant activities of essential oils and various extracts of Juniperns phoenicea L. (Cupressacees). J Food Sci. 2009;74:364-71.

5. Bodas R, Prieto N, López-Campos O, Giráldez FJ, Andrés S. Naringin and vitamin $\mathrm{E}$ influence the oxidative stability and lipid profile of plasma in lambs fed fish oil. Res Vet Sci. 2011:91:98-102

6. Delles RM, Xiong YL, True AD, Ao T, Dawson KA. Dietary antioxidant supplementation enhances lipid and protein oxidative stability of chicken broiler meat through promotion of antioxidant enzyme activity. Poult Sci. 2014;93(6):1561-70.

7. Kim YJ, Park WY, Choi IH. Effects of dietary a-tocopherol, selenium, and thei different combinations on growth performance and meat quality of broiler chickens. Poult Sci. 2010:89:603-8.

8. Liu F, Dai R, Zhu J, Li X. Xingmin. Optimizing color and lipid stability of beef patties with a mixture design incorporating with tea catechins, carnosine, and a-tocopherol. J Food Eng. 2010;98:170-7.
9. Ahn DU, Nam KC, Du M, Jo C. Volatile production in irradiated normal, pale soft exudative (PSE) and dark firm dry (DFD) pork under different packaging and storage conditions. Meat Sci. 2001;57(4):419-26.

10. Lund MN, Hviid MS, Claudi-Magnussen C, Skibsted L. Effects of dietary soybean oil on lipid and protein oxidation in pork patties during chill storage. Meat Sci. 2008;79:727-33.

11. Steel R, Torrie J, Dickey D. Principles and procedures of statistics: a biometric approach. New York: WCBMcGraw Hill Companies. Inc.; 1997.

12. Goliomytis M, Tsoureki D, Simitzis PE, Charismiadou MA, Hager-Theodorides $\mathrm{AL}$, Deligeorgis SG. The effects of quercetin dietary supplementation on broiler growth performance, meat quality, and oxidative stability. Poult Sci. 2014;93:1-6.

13. Muthukumar M, Naveena BM, Vaithiyanathan S, Sen AR, Sureshkumar K Effect of incorporation of Moringa oleifera leaves extract on quality of ground pork patties. J Food Sci Technol. 2012;25:1-9.

14. Capitani CD, Hatano MK, Marques MF, Castro IA. Effects of optimized mixtures containing phenolic compounds on the oxidative stability of sausages. Food Sci Technol Int. 2012;19(1):69-77.

15. Kumar D, Tanwar VK. Utilization of clove powder as phytopreservative for chicken nuggets preparation. J Stored Prod Postharv Res. 2011;2(1):11-4.

16. Ramana KV, Srivastava S, Singhal SS. Lipid peroxidation products in human health and disease. Oxid Med Cell Longev. 2013;2013:583438.

17. Spickett CM, Forman HJ. Lipid oxidation in health and disease (oxidative stress and disease). USA: CRC Press; 2015. p. 440.

18. Kanner J. Dietary advanced lipid oxidation endproducts are risk factors to human health. Mol Nutr Food Res. 2007;51(9):1094-101.

19. Ixtaina WY, Martinez ML, Spotorno V, Mateo CM, Maestri DM, Diehl BWK Nolasco SM, Tomas MC. Characterization of chia seed oils obtained by pressing and solvent extraction. J Food Compos Anal. 2011;24:166-74

20. Decker EA. Strategies for manipulating the prooxidative/antioxidative balance of foods to maximize oxidative stability. Trends Food Sci Tech. 1998;9:241-8.

21. Mancini RA, Hunt MC. Current research in meat color. Meat Sci. 2005;71 $100-21$

22. Muela E, Alonso V, Campo MM, Sañudo C, Beltrán JA. Antioxidant diet supplementation and lamb quality throughout preservation time. Meat Sci. 2014;98(2):289-95

23. Chandralekha S, Babu AJ, Moorthy PRS, Karthikeyan B. Studies on the effect of pomegranate rind powder extract as natural antioxidant in chicken meat balls during refrigerated storage. J Adv Vet Res. 2012;2:107-12.

24. Andrés S, Tejido ML, Bodas R, Morán L, Prieto N, Blanco C, Giráldez FJ. Quercetin dietary supplementation of fattening lambs at $0.2 \%$ rate reduces discolouration and microbial growth in meat during refrigerated storage. Meat Sci. 2013;93:207-12.

25. Serpen A, Gokmen V, Fogliao V. Total antioxidant capacities of raw and cooked meats. Meat Sci. 2012;90:60-5.

26. Fasseas MK, Mountzouris KC, Tarantilis PA, Polissiou M, Zervas G. Antioxidant activity in meat treated with oregano and sage essential oils. Food Chem. 2007:106:1188-94.

27. Ganhao R, Morcuended, Estevez M. Protein oxidation in emulsified cooked burger patties with added fruit extracts: Influence on colour and texture deterioration during chill storage. Meat Sci. 2010;85:402-9.

28. Jo SC, Nam KC, Min BR, Ahn DU, Cho SH, Park WP, Lee SC. Antioxidant activity of prunus mume extract in cooked chicken breast meat. Int J Food Sci Technol. 2006:41(1):15-9.

29. Ixtaina W, Nolasco SM, Tomas MC. Oxidative stability of chia (Salvia hispanica L.) seed oil: effect of antioxidants and storage conditions. J Am Oil Chem Soc. 2012;89:1077-90.

30. Guiotto EN, Ixtaina WY, Nolasco SM, Tomás MC. Effect of storage conditions and antioxidants on the oxidative stability of sunflower-chia oil blends. J Am Oil Chem Soc. 2014;91:767-76.

31. Huan $Y$, Zhou G, Zhao G, Xu X, Peng Z. Changes in flavour compounds of dry-cured Chinese Jinhua ham during processing. Meat Sci. 2005;71: 291-9.

32. Vieira C, Fernández-DIEZ A, Mateo R, Bodas R, Soto S, Manso T. Effects of addition of different vegetable oils to lactating dairy ewes' diet on meat quality characteristics of suckling lambs reared on the ewes' milk. Meat Sci. 2012;91:277-83.

33. Sivadier G, Ratel J, Bouvier F, Engel E. Authentication of meat products: 465 determination of animal feeding by parallel GC-MS analysis of three adipose tissues. J Agric Food Chem. 2008;56:9803-12. 
34. Calkins CR, Hodgen JM. A fresh look at meat flavor. Meat Sci. 2007;77:63-80.

35. Veberg A, Sørheim O, Moan J, lani V, Juzenas P, Nilsen AN. Measurement of lipid oxidation and porphyrins in high oxygen modified atmosphere and vacuum-packed minced turkey and pork meat by fluorescence spectra and images. Meat Sci. 2006;73:511-20.

36. Nam KC, Ko KY, Min BR, Ismail H, Lee EJ, Cordray J, Ahn DU. Effects of oleoresin-tocopherol combinations on lipid oxidation, off-odor, and color of irradiated raw and cooked pork patties. Meat Sci. 2007;75(1):61-70.

Submit your next manuscript to BioMed Central and we will help you at every step:

- We accept pre-submission inquiries

- Our selector tool helps you to find the most relevant journal

- We provide round the clock customer support

- Convenient online submission

- Thorough peer review

- Inclusion in PubMed and all major indexing services

- Maximum visibility for your research

Submit your manuscript at www.biomedcentral.com/submit 